\title{
Analysis of energy security and sustainability in future low carbon scenarios for Brazil
}

\begin{abstract}
This study estimated a series of indicators to assess the energy security of supply and global and local environmental impacts under different mitigation scenarios through 2050 in Brazil, designed with the integrated optimisation energy system model MESSAGE-BRAZIL. The assessment of interactions between environmental impacts and energy security dimensions was complemented through the application of life cycle assessment (LCA) methodology. Overall results imply energy security establishes more synergies than trade-offs in increasingly stringent mitigation scenarios, especially patent within the sustainability dimension, which increases energy security and provides additional benefits regarding climate change mitigation and air pollution emissions. It is still necessary to extend analysis to other energy sectors in addition to the power supply sector, to promote a better understanding of repercussions of energy scenario expansion in energy security.
\end{abstract}

Keywords: Energy assessment modelling; energy security of supply; life cycle assessment; climate change mitigation; Brazil.

\section{Introduction}

Historically, Brazil has been at the forefront in the use of renewable energies. The share of nonfossil resources, including hydropower, bioenergy and sugarcane ethanol has made up, on average, some $45 \%$ of the country's primary energy supply portfolio over the last ten years (EPE, 2014). However, this contribution has been declining. Over the past ten years, final energy consumption has increased by $43 \%$, from 182 to 260 million tonnes of oil equivalent (MTOE), greatly due to a rise in quality of life, typical for an emerging economy such as Brazil. On the other hand and on the supply side, the expansion of hydropower and bioenergy projects has been limited due to socio-environmental restrictions (Soito and Freitas 2011; Von Sperling, 2012; Nogueira et al., 2014; Lucena et al., 2015) and economic constraints (Moreira et al. 2014). As a result, whatever new hydroelectric projects yet to be built in the country should adopt runof-the-river technologies without pump-storage mechanisms, which implies in a lower capacity the regulation of monthly fluctuations of power demand and a reduced ability to mitigate the impacts of extreme weather events, such as droughts and floods (Lucena et al., 2009; Lucena et al., 2015). In recent years, Brazil has faced serious weather events, which have reduced production from hydropower and ethanol distilleries, highlighting the vulnerability of the country to climate change and weather uncertainty (Lucena et al. 2009; Schaeffer et al. 2012). 
Future scenarios project that Brazil's primary energy supply will roughly double by 2050 , as energy consumption per capita rises to global average levels (Lucena et al. 2015). Following a business-as-usual scenario, this growth will likely come from fossil fuel resources. Currently, fossil fuel thermal power - mostly natural gas - plants are used to complement hydropower production, but in the future they might be turned on continuously as base load plants, reducing the share of renewable energy sources in the total generation (Nogueira, et al. 2014; Lucena et al. 2015) ). In recent years, the Brazilian government has announced aggressive investments to explore pre-salt oil and natural gas reserves and even unconventional natural gas (shale and tight gas), aiming at fostering the resilience and diversity of the energy sector in general (Goldemberg et al. 2014), as well as providing financial resources for promoting socio-economic development programs ${ }^{1}$.

In this context, projecting future energy scenarios for Brazil and evaluating their implications in terms of sustainability and energy security of supply is at foremost relevance. In literature, numerous studies have focused on developing a framework for assessing energy security assessment and implications on a policy level (Blum and Legey 2012; Martchamadol and Kumar 2014; Sovacool and Mukherjee 2011; Löschel et al. 2010; Johansson 2013; Portugal-Pereira and Esteban 2014). Specifically, from the Brazilian perspective, Knox-Hayes et al. (2013) examine the energy security challenges that nations face and characterizes possible policy responses. Further, Nuttall and Manz (2008) consider future energy scenarios in BRICS countries with higher shares of renewables and the respective impacts of climate change and energy security. Also, the International Atomic Energy Agency (IAEA) and United Nations Department of Economic and Social Affairs (UN-DESA) (2007) developed a series of energy security of supply indicators and applied them to Brazil. However, to the authors' knowledge, few studies have quantitatively assessed the multidimensional aspects of energy security in Brazil. For instance, Schaeffer et al. (2005), Nogueira et al. (2014) and Lucena et al. (2015) assessed future energy scenarios in Brazil under different climate change mitigation policies, and quantified energy indicators. While relevant to the field, these studies did not quantify the multi-dimensional nature of energy security of supply, nor consider different sustainability and energy security points of view in a long-term perspective.

To bridge this gap, this paper quantifies energy indicators that reflect the interactions between environmental and economic dimensions of energy security of supply in Brazil for several energy portfolio scenarios through 2050 , and under different climate change mitigation strategies. To this end, a series of indicators has been developed based on the energy indicators for sustainable development (EISD) framework (IAEA, 2005), including the dimensions of energy use, energy intensity, foreign dependency and diversity of primary energy and power matrixes. Further, a life cycle assessment (LCA) approach has been applied to assess global and local environmental indicators, namely global warming potential (GWP), terrestrial acidification potential (TAP), particulate matter formation (PMF), stratospheric ozone depletion potential (ODP), water depletion and land use.

\footnotetext{
${ }^{1}$ Scenarios for the pre-salt oil fields indicate that oil production in the country would peak in 2027 at 4.9 million barrels a day (Mb/d), assuming a low reserves estimate (Saraiva et al. 2014), which is around twice the current oil production in the country.
} 
The paper is organized as follows: section 2 overviews the holistic concept of energy security of supply and its economic and environmental dimensions. In the methodological procedure, section 3, the assumptions of the energy scenarios and the indicator model framework are presented. Section 4 presents the projected energy security of supply and sustainability indicators, and encompasses a discussion of the implications on energy security of supply in its many dimensions, in the light of different energy mixes in Brazil through 2050. This is followed by final remarks in section 5 .

\section{Dimensions of energy security and sustainability}

Although energy security has been considered a crucial aspect in achieving the sustainable development goals, meeting its requirements may create conflict between two main pillars of sustainability: the economic and the environmental. Universal access to modern energy services has indubitably ensured socioeconomic welfare, but frequently at a high environmental cost, mainly due to high reliance on fossil fuels. Recurrent use of fossil-based energy sources has led to greenhouse gas (GHG) emissions, which have repercussions on both the economic and environmental dimensions of energy security of supply (IPCC, 2013; Martínez et al. 2015). Also, increasing dependence on imported energy resources raises concerns about the country's vulnerability to international oil shocks and volatile oil prices (e.g. Percebois 2007; Hedenus et al. 2010). On the other hand, increasing the concentration of GHG in the atmosphere contributes to climate change, which might lead to higher frequency and intensity of weather extreme events such as droughts, heat and cold waves, and floods (Cubasch et al. 2013; IPCC, 2013; Magrin et al., 2014). Therefore, the analysis of the multiple dimensions of energy security of supply, showing its linkages, potential trade-offs and co-benefits, is essential when assessing future energy scenarios.

Energy security of supply historically has been based on fossil fuel availability and resource scarcity (Greene 2010). However, in addition to concerns about resource scarcity, energy planners also have to guarantee that energy supply systems are capable of providing sufficient, affordable, stable, environmentally sustainable, and inclusive services to sustain the economic needs of a country (Portugal-Pereira and Esteban 2014). In this sense, concerns about environmental sustainability and social equity must be included when evaluating the security of energy systems. In this view, Vivoda (2010) recommends a more comprehensive approach when evaluating recent problems of energy markets and their implications on multiple dimensions of energy security of supply. Further, Sovacool and Mukherjee (2011) highlight that energy security assessments need to include questions about social equity, governance, affordability, reliability, efficiency, technological development, and global and local environmental constraints.

Several energy indices have been proposed in the literature to measure energy security and energy sustainability with a multitude of dimensions (Ren and Sovacool 2014; Ren and Sovacool 2015; Narula and Reddy 2015). Among them, the IAEA and UNDESA (2007) have proposed a comprehensive series of indicators to evaluate energy security within socioeconomic and environmental dimensions, enabling the assessment of energy related impacts. These so called EISD includes economic indicators for patterns of energy use and production, social indicators focusing on social welfare and universal access to clean energy services, and environmental 
indicators such as climate change, air, water and land pollution, and depletion issues (IAEA and UNDESA 2007).

\section{Methodological procedure}

To assess future energy portfolios in Brazil under different climate change mitigation policies and their implications for energy security of supply, this work is organized in three methodological stages, comprised of (i) future energy scenario building, (ii) energy optimisation model and (iii) indicator evaluation, as shown in Figure 1. The following sections describe each of these stages in detail.

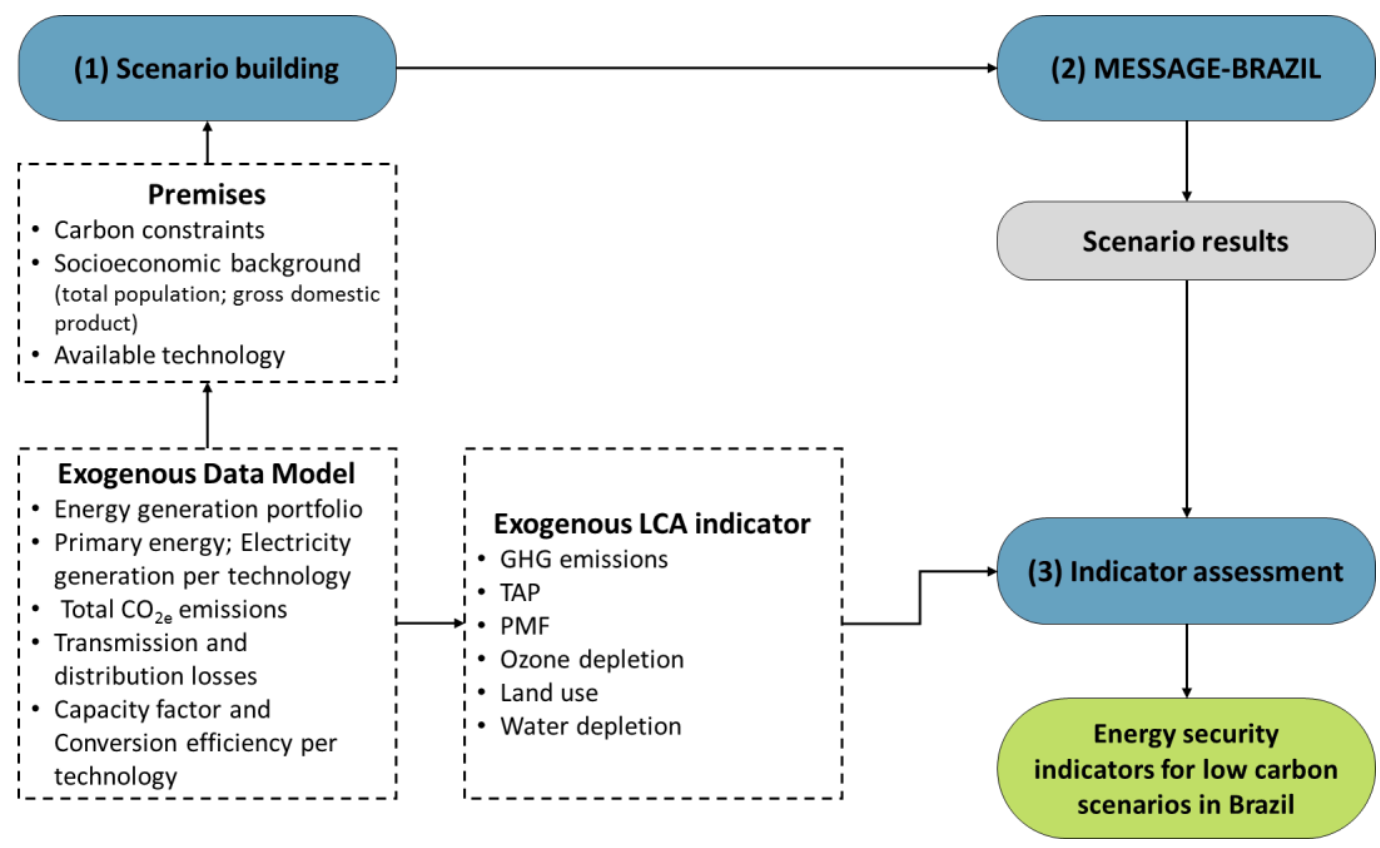

Figure 1. Stages in the methodological approach.

\subsection{Energy scenario building}

This paper uses future scenarios for the Brazilian energy sector produced with the Integrated Climate Modelling and Capacity Building and Latin American Modelling Project (CLIMACAPLAMP), using the MESSAGE-BRAZIL model (Lucena et al., 2015). These scenarios include different pathways for the Brazilian energy system under different scenarios of carbon taxes and abatement targets. The climate policy strategies simulated assume progressively stringent scenarios in terms of mitigation efforts, and will be used to assess the implications of mitigation strategies on sustainability and energy security.

A baseline scenario and four climate policy scenarios were simulated. The baseline scenario is based on a least cost evolution of the Brazilian energy system through 2050, under business-asusual assumptions. Four climate policy scenarios were simulated: two scenarios with $\mathrm{CO}_{2}$ price paths applied to all GHGs - Low Tax and High Tax -; and two others with emission reductions applied to all fossil fuel $\mathrm{CO}_{2}$ emissions - High Cap and Low Cap. Both sets of policies begin in 2020, and all other assumptions are the same as the baseline. Table 1 shows the values assumed 
of the $\mathrm{CO}_{2}$ prices and caps in the climate policy scenarios. For more details on the scenarios tested, see Lucena et al. (2015).

Table 1. $\mathrm{CO}_{2}$ price paths and emission reductions assumed by the climate policy scenarios.

\begin{tabular}{llrrrr}
\hline Scenario & Carbon price & $\mathbf{2 0 2 0}$ & $\mathbf{2 0 3 0}$ & $\mathbf{2 0 4 0}$ & $\mathbf{2 0 5 0}$ \\
\hline Low Tax & $(2005) \cup S \$ / \mathrm{tCO}_{2} \mathrm{e}$ & 10 & 15 & 22 & 32 \\
High Tax & $(2005) \cup S \$ / \mathrm{CCO}_{2} \mathrm{e}$ & 50 & 74 & 110 & 162 \\
\hline Scenario & Emission reduction & $\mathbf{2 0 2 0}$ & $\mathbf{2 0 3 0}$ & $\mathbf{2 0 4 0}$ & $\mathbf{2 0 5 0}$ \\
\hline Low Cap & \% Reduction from 2010 & 5 & 10 & 15 & 20 \\
High Cap & $\%$ Reduction from 2010 & 12.5 & 25 & 37.5 & 50 \\
\hline
\end{tabular}

\subsection{MESSAGE-BRAZIL and energy portfolios}

Power supply portfolio scenarios for Brazil with a 2050 horizon have been developed in the Model for Energy Supply System Alternatives and their General Environmental Impact tailored for a Brazilian context (hereafter referred to as MESSAGE-BRAZIL), as described in Nogueira et al. (2014). The MESSAGE-BRAZIL model is an integrated energy system model that projects the least cost expansion strategy for the Brazilian energy supply system to meet a certain exogenous energy service demand, and under specified constraints in terms of energy resource availability, industrial installation capacity of each technology, investment costs, and political, social and environmental constraints. To this end, the model minimizes the total cost for the entire energy system, and considers different primary fossil and renewable energy sources and the interaction among conversion technologies to produce the required energy services to end-use sectors (industrial, energy, transport, residential, agricultural and waste). The results of the model include a mix of energy carriers at different levels, from primary to final energy, that attend to demand for energy services at minimum cost (Annex). In this study, the results will focus on primary energy and electricity generation. For local impacts, only electricity generation is considered.

The representation of the Brazilian energy system in MESSAGE-BRAZIL is divided into three interconnected sub-systems: South-Southeast-Midwest; North-Northeast; and isolated systems. The model base year is 2010, and it runs on five-year steps through 2050 . Seasonal and daily profiles are divided in four seasons and five daily periods. MESSAGE-BRAZIL is an energy system expansion model and, as such, it does not account for detailed operational aspects of the electricity generation system. The integration of variable renewable electricity generation technologies is modelled in MESSAGE-BRAZIL via exogenous operational constraints. For further details see Lucena et al. (2010), Borba et al. (2012), Malagueta et al. 2014 and Nogueira et al. (2014).

\subsection{Description of EISD used}

This paper adopts the framework suggested by the IAEA (2005) to estimate the energy security indicators based on the simulated energy portfolio scenarios for Brazil through 2050. This approach focuses on energy system interactions within its economic and environmental dimensions, providing information that encourages decision makers to assess energy policies from a holistic perspective (IAEA, 2005). 
Attending to Brazilian specificities and the current policy debate about the energy supply expansion strategy, eight dimensions ${ }^{2}$ were selected to characterize the security of the energy supply in each of the five scenarios. Although these indicators do not capture all the dimensions of energy security and sustainability, they provide a good basis for evaluating these issues. These dimensions are summarized in

Table 2, and encompass economic and environmental aspects, as follows (IAEA, 2005):

- Use of energy: reflects patterns of primary energy and electricity consumption per capita use.

- Energy intensity: measures patterns of primary energy use and electricity consumption at the economic level. It results from the ratio between energy used and Gross Domestic Product (GDP), reflecting the energy intensity trend in the overall economy.

- Diversification of energy mix: describes the variety of energy resources in the primary energy and electricity portfolios. It is measured by the Shannon-Wiener index ${ }^{3}$, which takes into account the number of energy resources and their share in the energy matrix.

-Imported energy resource dependence: portrays the net dependence on energy resource imports. This indicator was calculated as the ratio between net energy imports and total primary energy.

- Global environmental sustainability: describes the global impacts of power supply systems on the environment, in terms of GWP $\left(\mathrm{CO}_{2} \mathrm{e}\right)$ and $\mathrm{ODP}\left(\mathrm{CFC}_{11} \mathrm{e}\right)$. Emissions have been estimated, taking into account the entire life cycle of the power generation systems. The system boundary includes the so-called Well-to-Meter, i.e., including upstream (extraction of fuels and raw materials, fuel processing and transportation) and downstream processes (operation of power plants to generate electricity, transmission and distribution to end users), and the construction of thermal power plant infrastructure (the so called "Cradle-to-Gate" cycle). Although direct and indirect land use change-related impacts are relevant and may significantly constrain the results, especially for bioenergy systems, the current system boundary excludes them. The MESSAGEBRAZIL model defines an upper limit of bioelectricity generation to guarantee that bioenergy does not affect other land uses nor drives deforestation. The life cycle assessment has been conducted by modelling input and output energy and mass streams with the SimaPro 8.0.1 software (Goedkoop et al. 2014). This indicator has been analysed in terms of carbon dioxide equivalent $\left(\mathrm{CO}_{2} \mathrm{e}\right)$, assuming the metrics of the IPCC AR4 4 (Solomon, S., D. Qin, M. Manning, Z. Chen, M. Marquis \& Miller 2007) and chlorofluorocarbons equivalent ( $\mathrm{CFC}_{11} \mathrm{e}$ ) (see the

\footnotetext{
${ }^{2}$ The ESID proposed by IAEA (2005) includes 30 indicators: 4 for the social dimension; 16 for the economic dimension; and 10 for the environmental dimension. This study focuses on a limited set of the economic and environmental indicators proposed by IAEA (2005).

${ }^{3}$ Shannon-Wiener index $H$ is estimated as follows: $H_{i}=-\sum_{i=1}^{n}\left(p_{i} \cdot \ln \left(p_{i}\right)\right)$, where $p_{i}$ is the proportion of resource $i$ in the energy matrix. High values of $H$ represent a diversified energy matrix. $\mathrm{H}$ is max when all types of $p_{i}$ are equally abundant.

${ }^{4} \mathrm{CO}_{2 \mathrm{e}}=\mathrm{CO}_{2}+23 \cdot \mathrm{CH}_{4}+296 \cdot \mathrm{N}_{2} \mathrm{O}$
} 
Environmental Protection Agency's (EPA) list of ozone depleting substances for more details) (EPA 2012).

- Local environmental impacts: refers to the environmental impacts of power generation systems at the local level in terms of TAP $\left(\mathrm{SO}_{2} \mathrm{e}\right), \operatorname{PMF}\left(\mathrm{PM}_{10} \mathrm{e}\right)$, water depletion ${ }^{5}$ and land use. This indicator has also been analysed following a life cycle approach.

Table 2 summarizes the economic and environmental dimensions, as well as EISD indicators considered in the present study. The selected dimensions are presented following a mid-point approach, i.e., results have not been weighted nor integrated into damage categories. Although weighting has been applied in multi-criteria analysis to Brazilian energy mix scenarios (Santos et al. n.d.), in the literature there is no consensus on how to select transparent and reliable weighting criteria, which is thus a subjective concept that would increase the uncertainty of the results.

Table 2. Dimensions and EISD indicators selected in the present study.

\footnotetext{
${ }^{5}$ In this work water depletion follows a definition proposed by ReCiPe method (Goedkoop et al. 2009). It includes water used from lakes, rivers, wells and unspecific natural origin. Therefore, it does not consider if water is returned to the original basin after usage or lost by evaporation or incorporation in other products and waste, transferred to different watersheds or disposed into fresh water sources.
} 


\begin{tabular}{|c|c|c|c|c|c|}
\hline & $\begin{array}{c}\text { Use and Production } \\
\text { Patterns }\end{array}$ & Energy Indicator & Description & Components & Unit \\
\hline \multirow{4}{*}{ 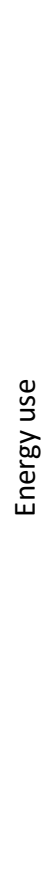 } & Use of primary energy & $\begin{array}{l}\text { Primary energy } \\
\text { use per capita }\end{array}$ & $\begin{array}{l}\text { Measures } \\
\text { primary energy } \\
\text { use per capita }\end{array}$ & $\begin{array}{l}\text { Ratio between } \\
\text { primary energy (PE) } \\
\text { and population } \\
\text { (capita) }\end{array}$ & $\frac{\text { toe }}{\text { capita }}$ \\
\hline & $\begin{array}{l}\text { Consumption of } \\
\text { electricity }\end{array}$ & $\begin{array}{l}\text { Electricity } \\
\text { consumption } \\
\text { per capita }\end{array}$ & $\begin{array}{c}\text { Measures } \\
\text { electricity } \\
\text { consumption per } \\
\text { capita }\end{array}$ & $\begin{array}{l}\text { Ratio between } \\
\text { consumed electricity } \\
\text { and population } \\
\text { (Electricity/capita) }\end{array}$ & $\frac{k W h}{\text { capita }}$ \\
\hline & Primary energy intensity & $\begin{array}{l}\text { Energy use per } \\
\text { unit of GDP }\end{array}$ & $\begin{array}{l}\text { Reflects the } \\
\text { consumption of } \\
\text { primary energy } \\
\text { and per GDP }\end{array}$ & $\begin{array}{l}\text { Ratio between total } \\
\text { primary energy use } \\
\text { and GDP (PE/GDP) }\end{array}$ & $\frac{\text { toe }}{(2010) U S \$}$ \\
\hline & $\begin{array}{l}\text { Electricity consumption } \\
\text { intensity }\end{array}$ & $\begin{array}{c}\text { Electricity } \\
\text { consumption } \\
\text { per unit of GDP }\end{array}$ & $\begin{array}{l}\text { Reflects the } \\
\text { consumption and } \\
\text { electricity per } \\
\text { GDP }\end{array}$ & $\begin{array}{c}\text { Ratio between } \\
\text { consumed electricity } \\
\text { and GDP } \\
\text { (Electricity/GDP) }\end{array}$ & $\frac{k W h}{(2010) U S \$}$ \\
\hline \multirow{2}{*}{ 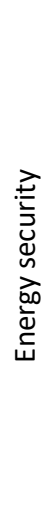 } & Diversification & $\begin{array}{l}\text { Fuel share in the } \\
\text { primary energy } \\
\text { and electricity } \\
\text { mix }\end{array}$ & $\begin{array}{c}\text { Shannon-Wiener } \\
\text { index }\end{array}$ & $\begin{array}{l}H_{i} \\
=\frac{-\sum_{i=1}^{n}\left(p_{i} \cdot \ln \left(p_{i}\right)\right)}{H_{\max }}\end{array}$ & $\%$ \\
\hline & $\begin{array}{l}\text { Imported energy } \\
\text { resource dependence }\end{array}$ & $\begin{array}{c}\text { Foreign } \\
\text { dependency } \\
\text { (FD) }\end{array}$ & $\begin{array}{l}\text { Measures } \\
\text { reliance on the } \\
\text { net energy } \\
\text { resource imports }\end{array}$ & $\begin{array}{l}\text { Ratio between } \\
\text { foreign energy (FE) to } \\
\text { total primary energy } \\
\qquad(\mathrm{PE}) \\
\mathrm{FD}=\frac{F E}{P E}\end{array}$ & Percentage \\
\hline \multirow{2}{*}{ 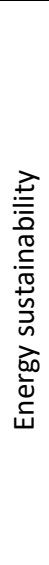 } & $\begin{array}{l}\text { Global warming potential } \\
\text { (GWP) }\end{array}$ & $\begin{array}{l}\text { Global } \\
\text { environmental } \\
\text { sustainability }\end{array}$ & $\begin{array}{c}\text { Measures } \\
\text { emissions of } \\
\text { greenhouse gases } \\
\text { (GHGs) from } \\
\text { power generation } \\
\text { yearly }\left(\mathrm{CO}_{2} \mathrm{e}\right)\end{array}$ & $\begin{array}{c}\mathrm{CO}_{2} \mathrm{e}=\text { share of } \\
\text { resource } i \cdot \mathrm{GHG} \text { of } \\
\text { resource } i\end{array}$ & $\frac{M t}{y}$ \\
\hline & $\begin{array}{l}\text { Stratospheric ozone } \\
\text { depletion (SOD) }\end{array}$ & $\begin{array}{l}\text { Global } \\
\text { environmental } \\
\text { sustainability }\end{array}$ & $\begin{array}{c}\text { Measures } \\
\text { emissions of } \\
\text { chlorofluorocarb } \\
\text { ons }\left(\mathrm{CFC}_{11} \mathrm{e}\right) \text { from } \\
\text { power generation } \\
\text { yearly }\end{array}$ & $\begin{array}{l}\mathrm{CFC}_{11} \mathrm{e}=\text { share of } \\
\text { resource } i \cdot \mathrm{CFC}_{11} \mathrm{e} \text { of } \\
\text { resource } i\end{array}$ & $\frac{t}{y}$ \\
\hline
\end{tabular}




\begin{tabular}{|c|c|c|c|c|}
\hline $\begin{array}{c}\text { Terrestrial acidification } \\
\text { potential (TAP) }\end{array}$ & $\begin{array}{l}\text { Local } \\
\text { environmental } \\
\text { protection }\end{array}$ & $\begin{array}{c}\text { Measures } \\
\text { emissions of } \\
\text { acidification air } \\
\text { pollutants }\left(\mathrm{SO}_{2} \mathrm{e}\right) \\
\text { from power } \\
\text { generation yearly }\end{array}$ & $\begin{array}{c}\mathrm{SO}_{2} \mathrm{e}=\text { share of } \\
\text { resource } i \cdot \mathrm{SO}_{2} \mathrm{e} \text { of } \\
\text { resource }\end{array}$ & $\frac{t}{y}$ \\
\hline $\begin{array}{l}\text { Particulate matter } \\
\text { formation (PMF) }\end{array}$ & $\begin{array}{l}\text { Local } \\
\text { environmental } \\
\text { protection }\end{array}$ & $\begin{array}{c}\text { Measures } \\
\text { emissions of } \\
\text { particulate } \\
\text { matter equivalent } \\
\left(\mathrm{PM}_{10} \mathrm{e}\right) \text { from } \\
\text { electricity } \\
\text { generation yearly }\end{array}$ & $\begin{array}{c}\mathrm{PM}_{10} \mathrm{e}=\text { share of } \\
\text { resource } i \cdot \mathrm{PM}_{10} \mathrm{e} \text { of } \\
\text { resource }\end{array}$ & $\frac{t}{y}$ \\
\hline Land use & $\begin{array}{l}\text { Local } \\
\text { environmental } \\
\text { protection }\end{array}$ & $\begin{array}{l}\text { Measures land } \\
\text { occupation to } \\
\text { generate } \\
\text { electricity from } \\
\text { different } \\
\text { resources }\end{array}$ & $\begin{array}{l}\mathrm{LU}=\text { share of } \\
\text { resource } i \cdot \text { Land } \\
\text { occupation of } \\
\text { resource }\end{array}$ & $\mathrm{km}^{2} \cdot y$ \\
\hline Water depletion & $\begin{array}{l}\text { Local } \\
\text { environmental } \\
\text { protection }\end{array}$ & $\begin{array}{l}\text { Measures water } \\
\text { used and } \\
\text { depleted to } \\
\text { generate } \\
\text { electricity from } \\
\text { different } \\
\text { resources }\end{array}$ & $\begin{array}{l}\text { WD }=\text { share of } \\
\text { resource } i \cdot \text { water } \\
\text { consumed by } \\
\text { resource }\end{array}$ & $\frac{m^{3}}{y}$ \\
\hline
\end{tabular}

\section{Energy security and sustainability interactions under different policy scenarios}

\subsection{Scenario results}

The share of energy sources in the primary energy and power generation portfolios is shown in Figure 2. Similarly to previous studies (Nogueira et al. 2014; Lucena et al. 2015) the baseline, which reflects a least cost scenario for system expansion, incorporates a large share of fossil fuels in the energy portfolios to fulfil demand through 2050. On the other hand, in the alternative scenarios there is a shift toward increasing renewable/less fossil fuel dependent energy mixes as climate policies become more stringent. 


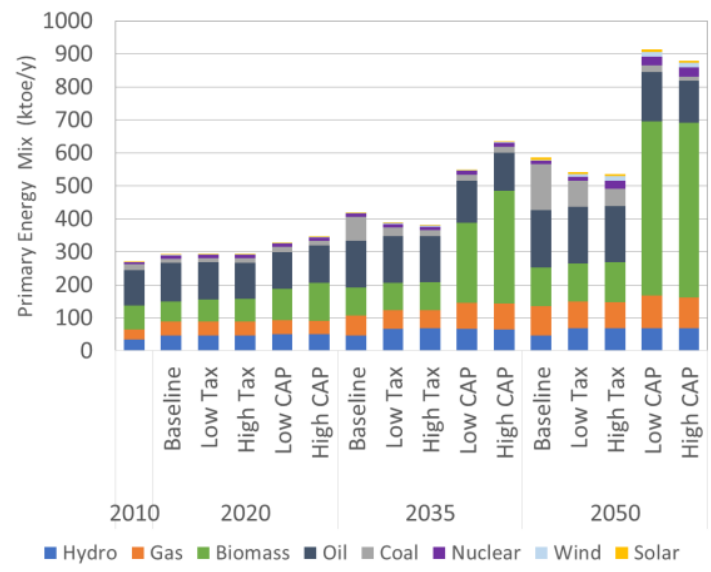

(a)

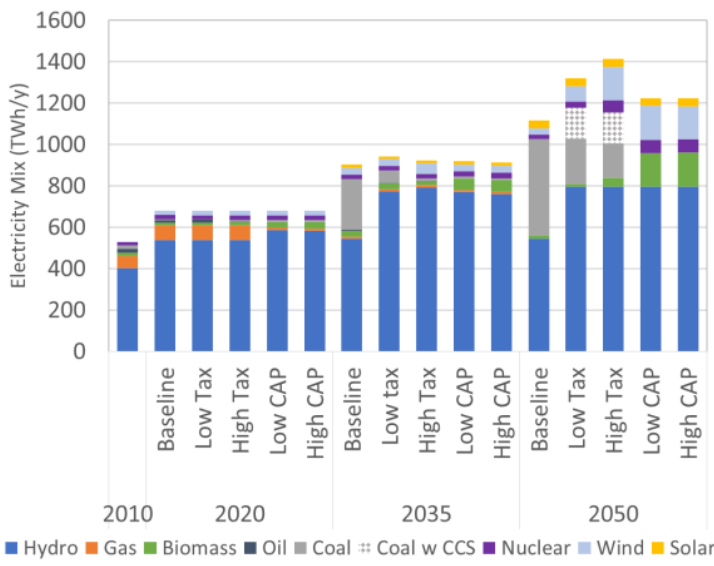

(b)

Figure 2. Share of energy sources in scenarios for primary energy (a) and power generation mix (b).

Under baseline conditions, primary energy demand increases twofold from 260 to 586 ktoe between 2010 and 2050. To meet this increasing demand, the primary energy supply relies on fossil fuels, largely on oil products and coal, and to a lesser extent on natural gas. A similar trend is observed in the power sector. The power supply is expected to double over time, reaching 1115 TWh in 2050. As the potential for hydropower expansion depletes between 2020 and 2030, the dependence on conventional coal technologies rises to attend to the increasing power demand through 2050.

If climate policy instruments were implemented, the share of renewable energies and carbon capture and storage (CCS) technologies would increase in both primary energy and power generation mixes, along with a lower dependence on conventional coal technologies. In 2050, in carbon taxation scenarios, renewable energies contribute to about $36-39 \%$ of the total primary energy supply, while low carbon technologies (renewables and CCS) account for $81-84 \%$ of the power generation matrix. Carbon abatement scenarios, as expected, reveal a higher share of renewables with a high participation of bioenergy, accounting for a total share of renewables of $68-70 \%$.

In terms of renewable energy, the importance of biomass increases as mitigation policies become more rigorous. In abatement scenarios, biomass becomes the major primary energy source in climate policy scenarios. Solar and wind increase in climate mitigation scenarios, but do not reach a relevant share by the end of the period.

In both cap scenarios, electricity generation reaches negative direct emission levels due to bioCCS. It should be noted that primary energy consumption increases as biomass is more intensively used, since conversion efficiency for this source is relatively low, yielding less final energy for the same amount of primary energy. In addition, due to energy penalties related to carbon capture, coal-fired power plants equipped with CCS will also require more coal. 


\subsection{Socioeconomic indicators}

Socioeconomic indicators are expressed in terms of energy (primary and electricity) consumption per capita and energy intensity (primary energy and electricity consumption per unit of GDP). GDP is exogenous to MESSAGE- BRAZIL, as well as the demand for energy services. However, primary and final energy consumption are endogenous model results, which may vary across scenarios ${ }^{6}$.

As shown in Figure 3, baseline and climate policy scenarios reveal an upward trend in primary energy and electricity consumption per capita, driven by expected economic growth and increase in quality of life. On the other hand, energy intensity stabilizes over time, which reveals that energy consumption would start to decouple from economic growth.

Following a baseline trend, primary energy consumption per capita doubles over the evaluated period. Carbon abatement scenarios demonstrate a higher increase when compared to the baseline, while carbon taxation scenarios show a rising trend, but slightly lower than the baseline.

A similar tendency is observed for electricity consumption. The baseline scenario suggests a $76 \%$ rise in power consumption when compared to the 2010 level, whereas both carbon taxation and abatement scenarios reveal a higher increase, between $94 \%$ and $123 \%$. Energy intensity, on the other hand, is expected to slightly decline over the evaluated period. In the baseline and carbon taxation scenarios, primary energy intensity is 70\% lower than 2010 levels, whereas in the carbon abatement alternatives, energy intensity is $10 \%$ higher than in 2010 . As for electricity intensity, all scenarios suggest a declining trend, sharper in the baseline scenario (70\%) and in the carbon abatement options (75\%) than in the carbon taxation scenarios (87\%).

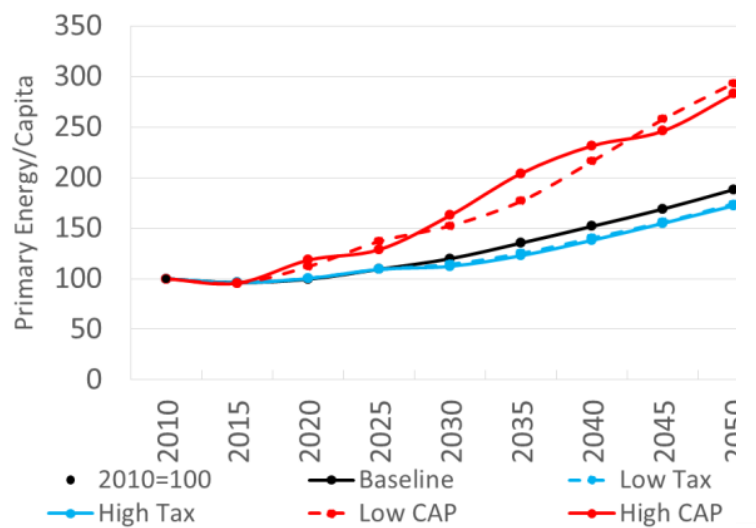

(a)

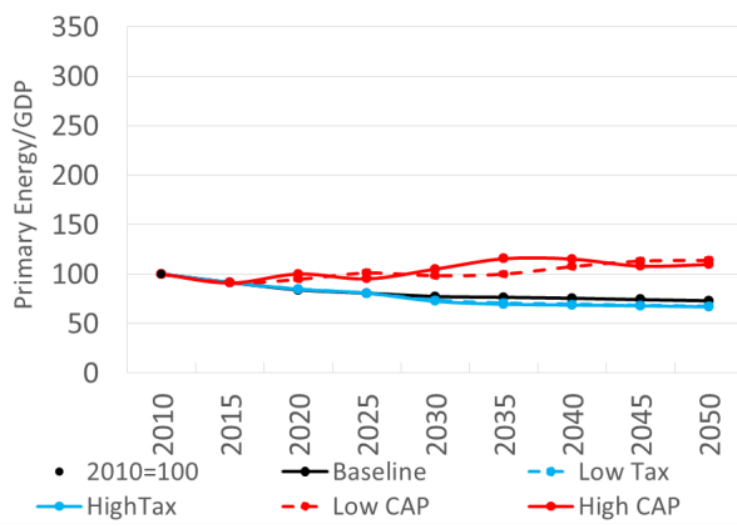

(b)

\footnotetext{
${ }^{6}$ It should be noted, however, that the version of MESSAGE-BRAZIL used in this study has a limited portfolio of demand side mitigation options.
} 

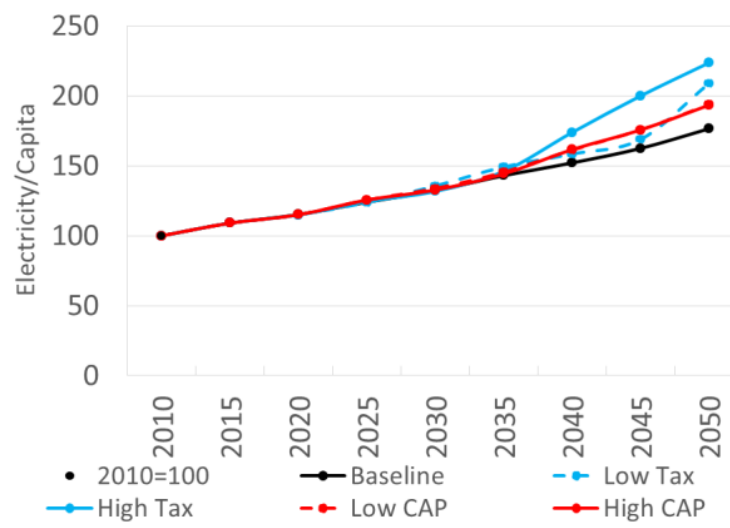

(c)

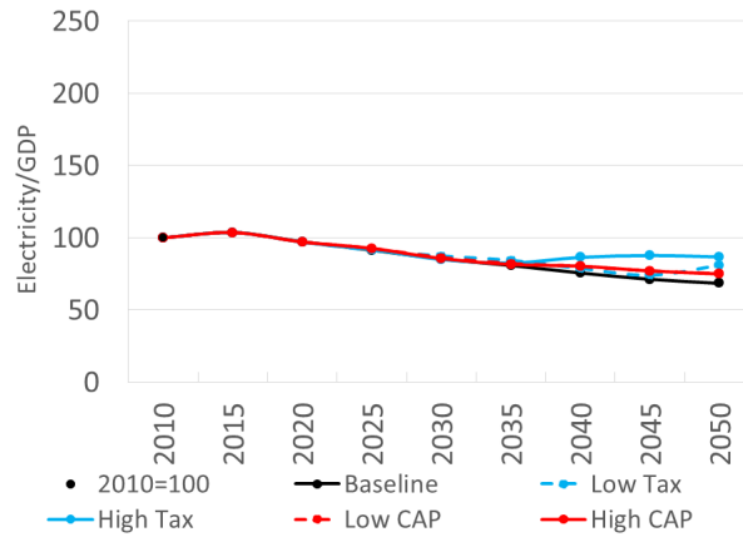

(d)

Figure 3. Socioeconomic indicators for primary energy ( $a$ and b panels) and electricity generation mix (c and d panels).

\subsection{Diversity of the energy mix}

The energy diversity index evaluates the variety of sources in the primary energy and power generation portfolios, as illustrated in Figure 4. The Shannon-Wiener indexes of each scenario have been normalized by the maximum Shannon-Wiener index, which is given by the $I n$ of the total number of energy sources. The closer the diversity index is to $100 \%$ the more diverse the mix is (i.e., $100 \%$ means an equal distribution of energy resources).

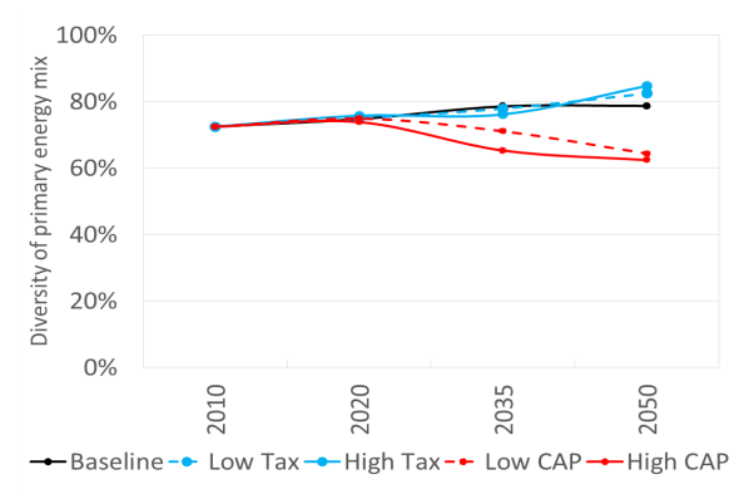

(a)

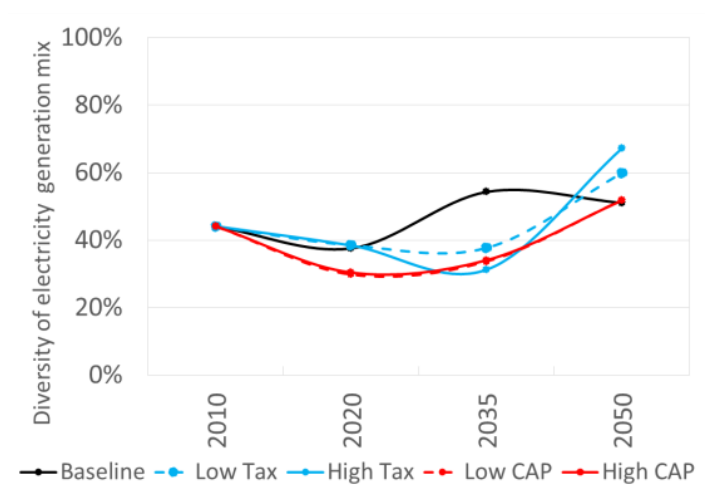

(b)

Figure 4. Energy mix diversity- indexes for primary energy supply (a) and electricity generation (b).

The diversity of the primary energy portfolio slightly rises over time, increasing from $72 \%$ in 2010 to $79 \%$ in 2050 , under baseline conditions. As the hydropower share decreases, fossil fuels and alternative energies increase their shares, which results in a more diverse mix. Carbon taxation scenarios indicate a higher diversity index (82-85\%) than the baseline scenario because these scenarios resulted in a higher share of bioenergy and advanced renewable energies, in detriment of oil and coal. Carbon abatement scenarios, on the other hand, reveal a lower diversity of the primary energy mix (62\%) than the baseline trend. While these options promote the use of renewable energies and restrict the share of fossil fuels, the mix is less diverse as bioenergy (58$60 \%)$ dominates the primary energy mix. 
The power generation mix is less diverse than the primary energy mix, since the role of hydropower is currently and should continue to be significant in electricity production. However, as hydropower expansion potential dwindles over time, a greater variety of energy sources will contribute to electricity generation. Thus, this combination reveals an increasing diversification of the mix. In 2050, all scenarios reveal a more diverse mix (52-67\%) when compared to 2010 $(44 \%)$.

\subsection{Foreign Energy Dependence}

Foreign energy dependence here is measured by the ratio of net foreign energy to total primary energy consumption. Positive values show net energy imports and a higher dependence on foreign resources, whereas negative values show net energy exports and thus a lower dependence on foreign resources. This indicator has been represented in two different ways, either taking into consideration oil trade (Figure 5a) or disregarding it (Figure 5b). Brazil has large offshore petroleum reserves. Despite the large uncertainties regarding the amount of ultimately recoverable resources in the recently discovered pre-salt offshore fields, some studies estimate sustained oil production at levels higher than $4 \mathrm{Mb} / \mathrm{d}$ for almost 30 years $^{7}$ (Saraiva et al. 2014). This figure is almost twice the current petroleum production in Brazil, and would lead the country to a large oil exporting position.

In 2010, Brazil was a net energy importer. However, in all scenarios energy dependence considerably drops and bottoms out around 2020 and 2025, implying a decrease in the country's external energy dependence and a subsequent rise of energy commodity exports. This pathway is mostly determined by the surplus production of oil, which is, in the model, exported to other countries. In all scenarios, oil production follows Hubert-like production pathways as projected by Saraiva et al (2014), assuming different probabilities of reserve addition. Nevertheless, in all scenarios, oil production peaks in the 2030's, reducing the surplus that is exported. And in some scenarios, this eventually would lead to a situation of net primary energy importer.

Excluding petroleum, results reveal foreign dependence on other fossil energy sources, mainly coal and natural gas (on average, coal and gas account for $40 \%$ and $60 \%$ of primary energy imports in non-cap scenarios, respectively). Given the low quality of Brazilian coal resources, an increased use of coal in Brazil would have to come from imports. Thus, in scenarios in which coal is used in power generation (with or without CCS), the foreign primary energy dependence would be higher. Brazil is currently a natural gas importer, and expected increase in domestic production should not be enough to meet the growing demand. In carbon abatement target scenarios (Caps), the reduction in the use of fossil fuels and the use of domestic biomass greatly reduces Brazil's foreign energy dependence on primary energy.

\footnotetext{
${ }^{7}$ It should be noted that MESSAGE-BRAZIL is a country specific model and, therefore, has a limited ability to model the effects of mitigation policies on the international energy trade.
} 


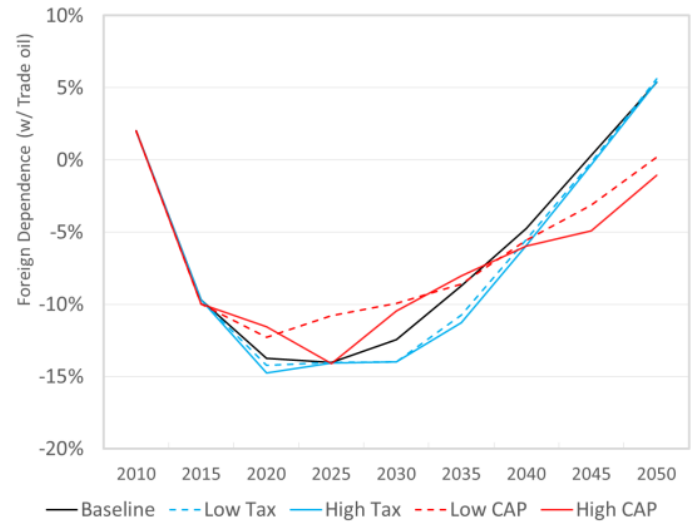

(a) with oil trade

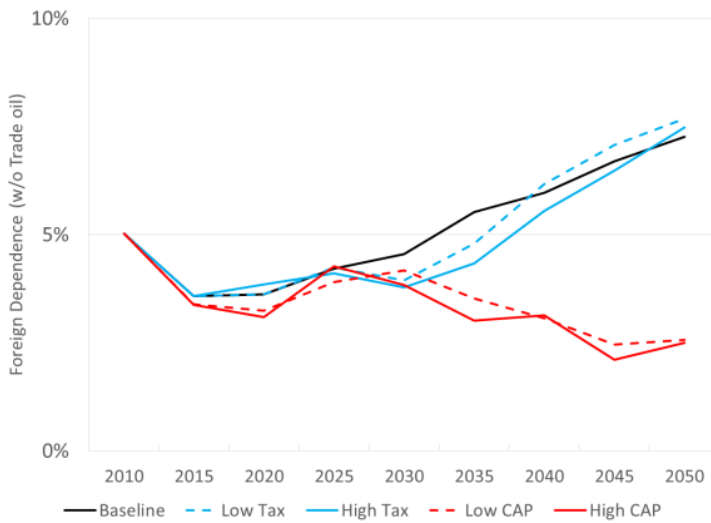

(b) without oil trade

Figure 5. Foreign Energy Dependence.

\subsection{Environmental Indicators}

The environmental performance of baseline and climate policy scenarios on the power generation portfolios were evaluated in terms of GWP, TAP, PMF, ODP, water depletion, and land use.

Figure 6 and Figure 7 reveal the GWP and PMF indicators, respectively, for all scenarios. In a reference scenario, power generation dependence on fossil fuels leads to a sharp rise in GHG and local air pollutants. Thus, from 2010 to 2050, GWP increases fivefold, from 114Mt in 2010 to $553 \mathrm{Mt}$ in 2050. During the same period, PMF potential doubles from 103 thousand tonnes in 2010 to 307 thousand tonnes in 2050. Conventional coal technologies become the main polluters, as they present a higher share in the power generation mix and emit elevated amounts of particulate matters per unit of generated power. As stated earlier, once hydropower expansion potential dwindles, the increasing power demand in the baseline is supplied by conventional coal technologies, which are responsible for large emissions of carbon dioxide and local air pollutants. 


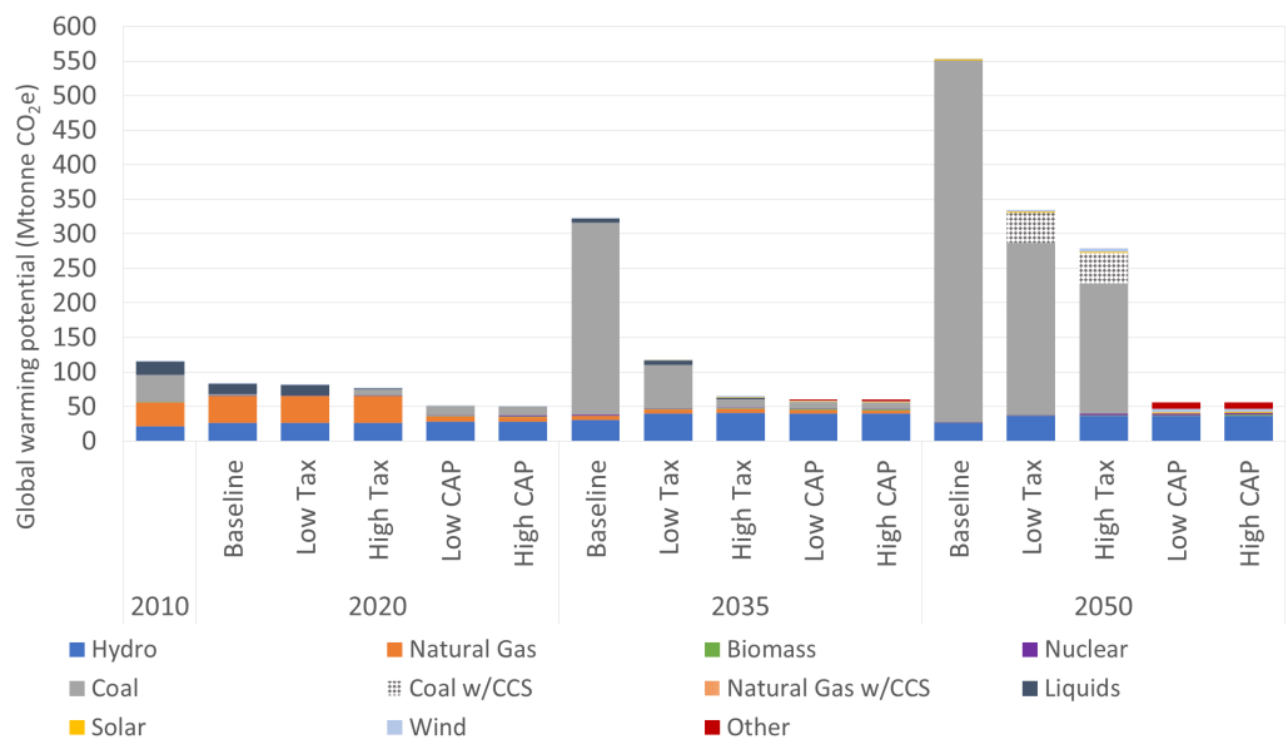

Figure 6. Global warming potential of power generation portfolios.

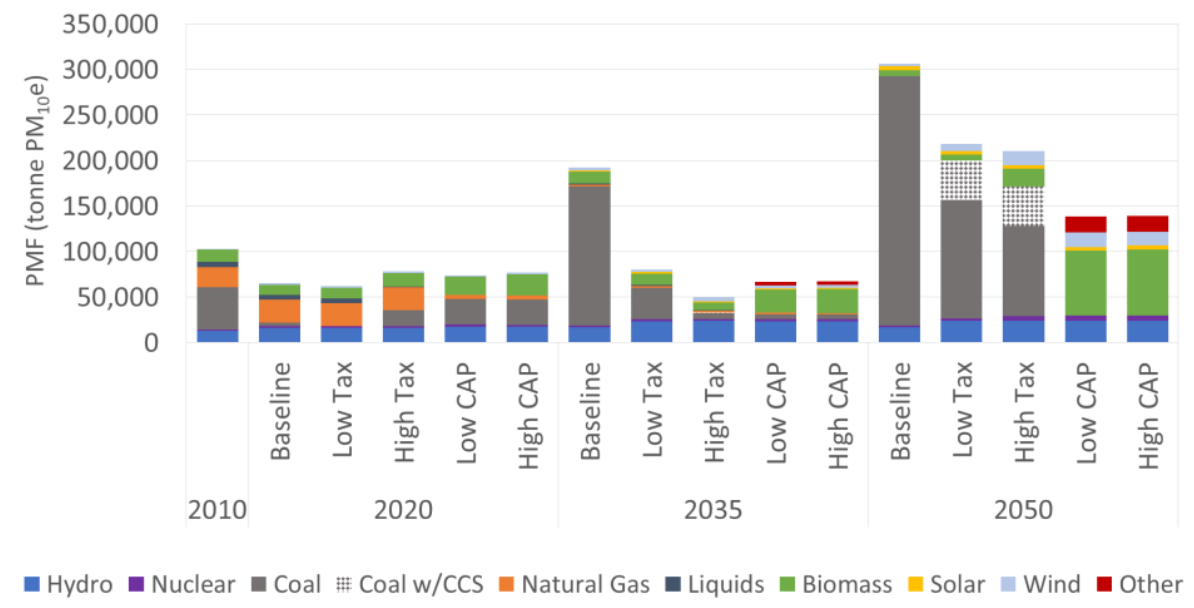

Figure 7. Particulate matter formation potential of power generation portfolios.

In the carbon tax scenarios, the least cost solution resulted in conventional coal facilities becoming equipped with CCS technologies, so GHG emissions decrease drastically. In the Low and High tax scenarios, GHG emissions fall by $40 \%$ and $50 \%$, respectively, when compared to the baseline. In the same thread, carbon taxation scenarios promote a reduction of PMF potential, which suggests that enacting a tax on carbon is effective in tackling local air pollution from coal thermal power plant technologies.

Cap scenarios also converge toward reducing both GWP and PMF impacts when compared to the baseline scenario in 2050. Low and high Cap scenarios registered accentuated GHG mitigation comparatively to the baseline scenario by drastically reducing the use of coal. Although emissions caps are different in the two scenarios, emissions from electricity generation are similar in both scenarios. MESSAGE- BRAZIL is an integrated model, which includes all 
energy related emissions. However, Figure 6 presents only emissions from electricity generation. The major emission differences between the two scenarios come mostly from other sectors, specifically, the industrial and transportation sector. These have higher decarbonisation costs when compared to electricity generation (this result is supported by IPCC, 2014; Lucena et al, 2015).

In terms of PMF, however, Cap scenarios reveal a limited reduction. Although Cap scenarios mitigate PMF when compared to the baseline scenario in 2050, impacts are still higher than the baseline in 2010. This is due to the high share of biomass combustion technologies, which results in high emissions of particulate matter.

Regarding both water depletion and land use, results show an upward trend in all scenarios. Figure $8 \mathrm{a}$ reveals the contribution of power generation to water depletion and Figure $8 \mathrm{~b}$ shows the results, excluding the contribution of hydropower. Hydropower has been excluded from the figure since its use is basically the same across policy scenarios (being slightly lower in the baseline). Also, hydropower impacts on water are significantly higher, therefore masking the contribution of other technologies to the overall water depletion impacts. In the baseline, overall impacts on water usage increase from 2.6 to 3.5 trillion $\mathrm{m}^{3}$, a rise of $30 \%$ compared to the 2010 level. The increasing share of hydropower capacity is the main driver for water depletion, and to a lesser extent coal, nuclear, solar and wind power technologies. Climate policy scenarios, on the other hand, reveal a sharper increase on used water, when compared to the baseline scenario. Both carbon taxation and carbon abatement scenarios suggest a twofold increase in the usage of water resources. This is mainly due to increasing shares of hydropower, coal thermal power plants equipped with CCS facilities, nuclear, solar and wind power technologies. While these technologies generate limited impacts in terms of GWP and local air pollution, they are major users of water resources (Merschmann et al. 2013). Large reservoir dams result in large quantities of evaporated water. Nuclear thermal power plants, in turn, need a large amount of water for the cooling systems in the turbine systems and reactor fuel rods. Overall, nuclear power plants withdraw more water per unit of generated power than equivalent coal power plants, as nuclear reactors operate at a lower temperature and lower turbine efficiency and do not release heat through smokestacks (under regular safety conditions) (World Nuclear 2013). Finally, solar and wind power infrastructure withdraw large amounts of water during production and assembly of facilities. 

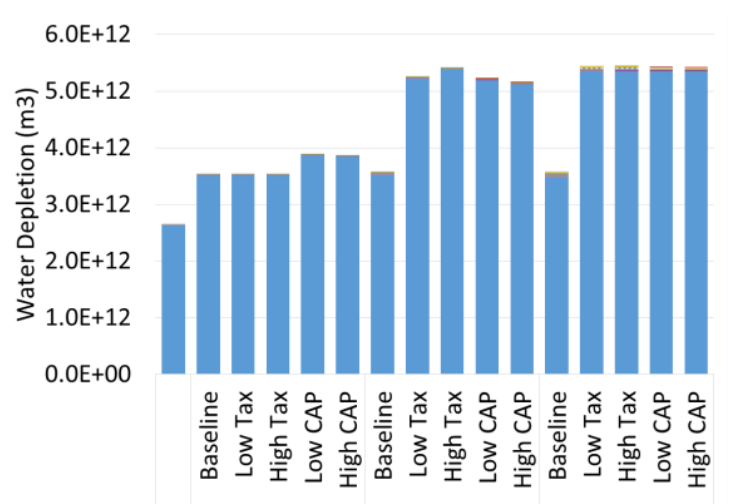

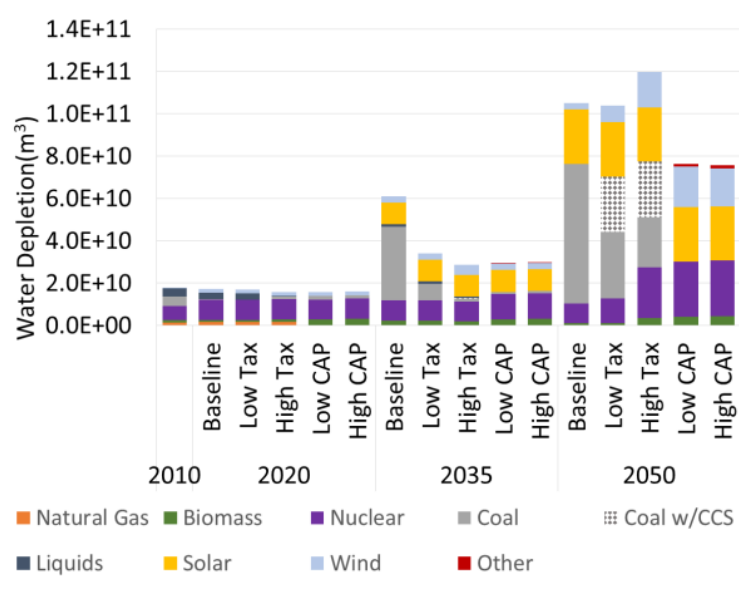

(b) Excluding hydropower

(a) Including all energy systems

Figure 8. Water depletion potential of power generation portfolios (excluding hydropower).

Figure 9a illustrates the land use impacts of power generation technologies, while

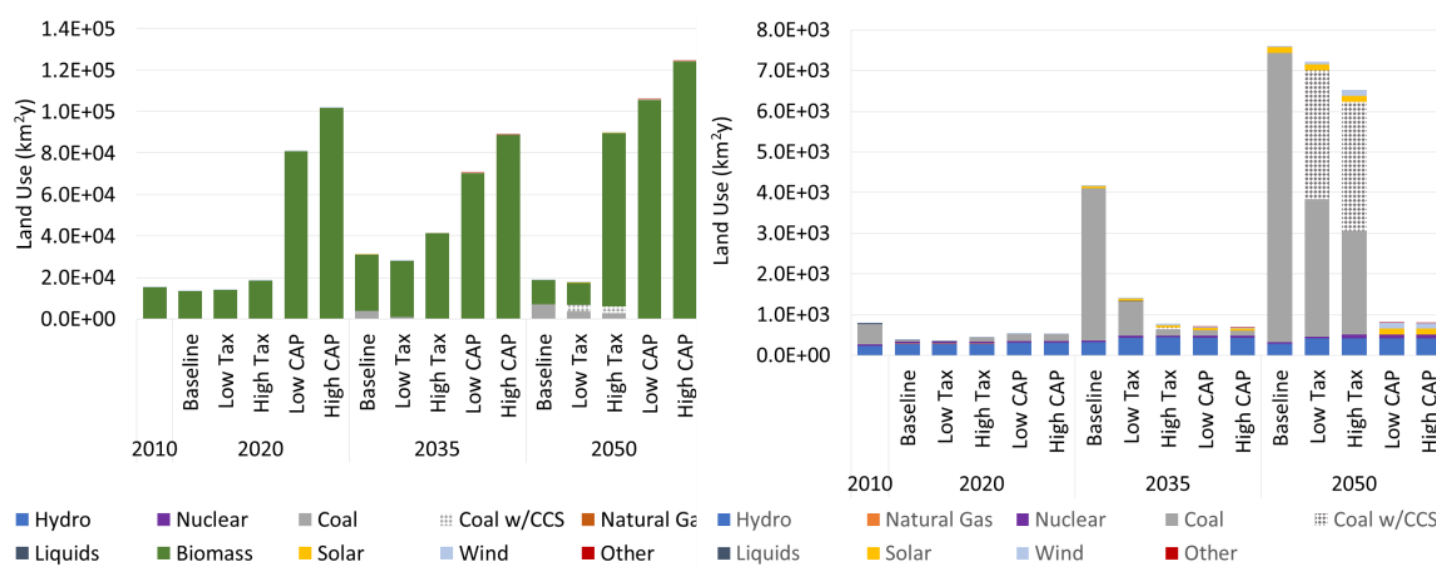

(a) Including all energy systems

(b) Excluding bioenergy

Figure $9 \mathrm{~b}$ presents the results, excluding bioenergy systems. In 2050, the baseline and carbon tax scenarios reveal a $30 \%$ reduction of land needed for generating electricity, compared to 2010. Carbon abatement scenarios, on the other hand, show a sevenfold increase in land use. Power expansion in the baseline and carbon tax scenarios rely mainly on conventional and advanced coal technologies, which have a limited land use footprint. Carbon abatement scenarios, however, suggest an increasing share of bioenergy systems, which requires large use of land per unit of generated electricity. 


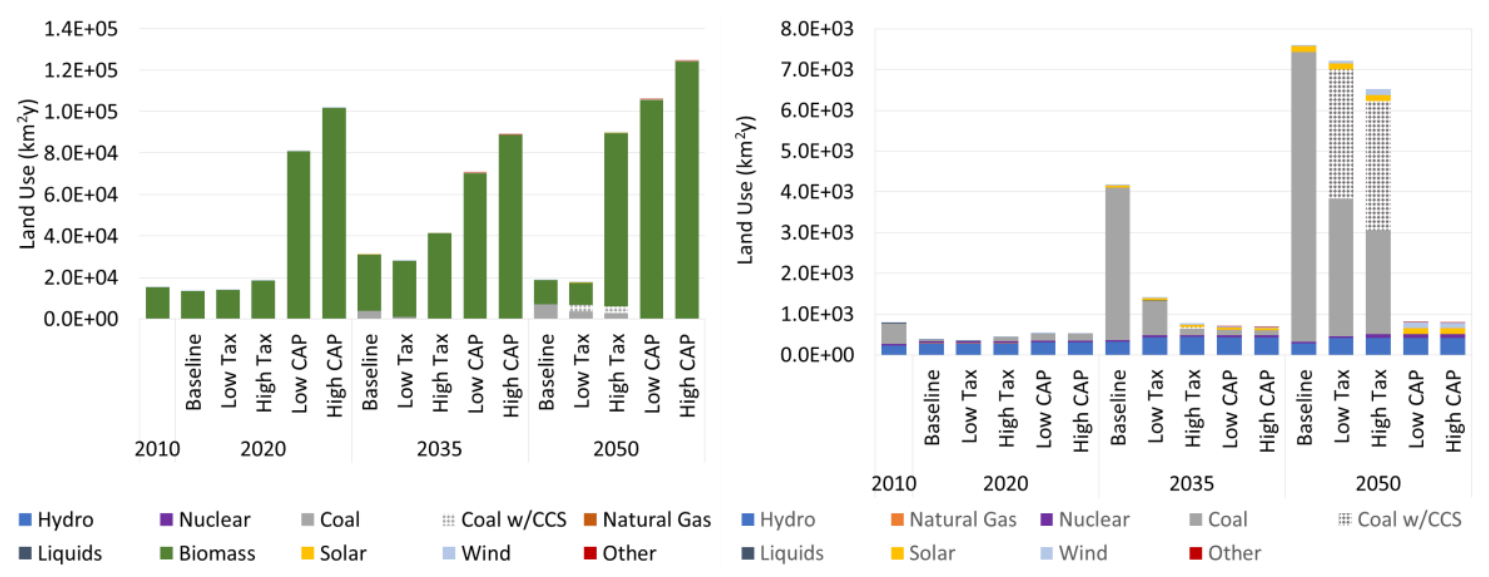

(a) Including all energy systems

(b) Excluding bioenergy

Figure 9. Land use of power generation portfolios.

\subsection{Discussion}

Currently, Brazil's primary energy and power generation mix are relatively clean when compared to the world average. However, energy demand is expected to increase as the result of economic development and improved quality of life of the population. Following a least cost trend, this increasing demand will be fulfilled, in the mid-term, by the expansion of hydropower generation capacity. However, constructing large reservoir hydropower plants is a controversial issue in Brazil. The majority of the remaining potential is located in the Amazon region, where the construction of dams generates high environmental and social impacts. Thus, whatever hydropower expansion occurs will be limited to run-of-the-river projects with small reservoirs. While these plants have lower local impacts, they are more vulnerable to weather extreme events (droughts and heavy precipitation). In the long term, as hydropower expansion dwindles, different technologies are available for expanding electricity generation capacity. In the least cost baseline scenario, the optimisation model shows a high penetration of conventional coal technologies. In climate policy scenarios, different alternatives are contemplated, including different renewables sources and CCS.

In terms of energy security of supply, the baseline scenario reveals a critical dilemma. As expected, levels of energy per capita steadily increase over time. Although the energy intensity tends to stabilize over the evaluated period, the optimized primary energy supply predicts high dependence on conventional coal technologies, while advanced and renewable systems have a limited penetration. While Brazil has significant coal reserves in the Southern part of the country, national reserves nonetheless have low heating value and high ash content, which reduce the efficiency of coal conversion into electricity and create operational problems. Thus, under a baseline scenario, future coal thermal power plants would be supplied by imported fuel. As a consequence, dependence on foreign resources, excluding petroleum, increases threefold by 2050. Besides the increase in foreign dependence, the baseline scenario also leads to higher impacts regarding all environmental indicators. As the energy supply relies on fossil resources 
and conventional thermal power technologies, GHG and local air pollutant emissions sharply rise. Furthermore, depletion of water resources and land use increase under baseline conditions.

Figure 10 shows the energy security and sustainability indicators of low-carbon scenarios relative to 2010, and the baseline scenario in 2035 and 2050. The results of the scenario simulation performed here show that if climate change mitigation policies were implemented, there could be some synergies/trade-offs in other security and sustainability dimensions when compared to the baseline and, in some cases, even to 2010.

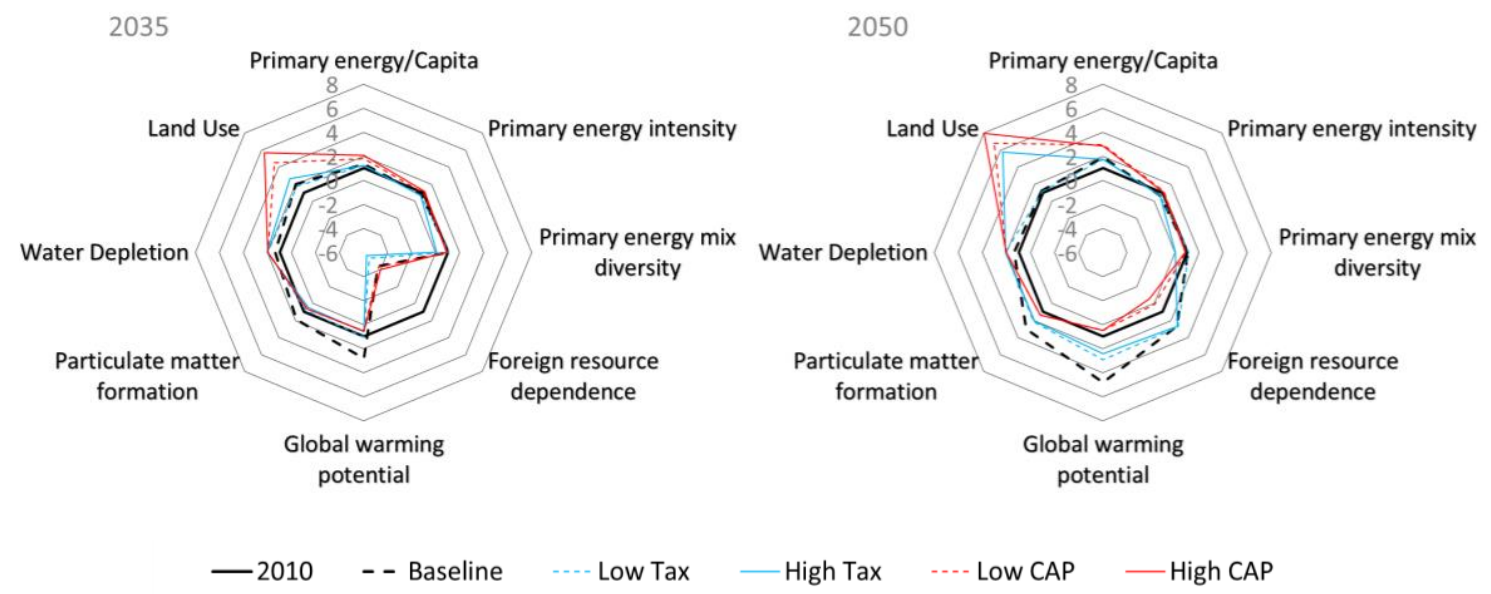

(a)

(b)

Figure 10. Security and sustainability indicators in 2035 (a) and 2050 (b). Note: values in index numbers $(2010=1)$

If a carbon tax regime were implemented, the optimisation model suggests that coal plants equipped with CCS facilities would become cost-competitive with other electricity generation technologies. Thus, expansion of primary energy supply and power generation would rely heavily on advanced coal technologies. This goes in line with previous studies conducted about future energy scenarios in Brazil (Nogueira et al. 2014; Lucena et al. 2015; Herreras Martínez et al. 2015). Nonetheless, these scenarios are not effective in reducing dependence on foreign energy resources. On the contrary, CCS facilities have an energy penalty, which results in higher coal consumption per unit of electricity generated. Thus, a carbon tax regime would raise upstream energy consumption, as well as methane and $\mathrm{CO}_{2}$ emissions associated with coal mining. Nonetheless, these scenarios would effectively tackle the overall GHG emissions of the energy supply sector. Further, they would bring co-benefits in terms of local air pollution (measured as PMF), as tailpipe emissions in advanced thermal power plants also declined. However, if comparing carbon tax scenarios in 2050 with 2010 levels, impacts on GHG and local air pollutants are not mitigated. Further, while compliant with mitigation of GHG and local air pollutant emissions, carbon tax scenarios do not show co-benefits in terms of depletion of water resources and land use. These scenarios result in higher impacts, as low carbon technologies require more land and water use per unit of supplied primary energy. 
Under carbon abatement (Cap) scenarios, the optimized mix reveals an increasing share of bioenergy with CCS facilities, as well as a higher penetration of bioenergy, solar and wind power systems. This mix of technologies guarantees an effective reduction of GHG and local air pollutant emissions when compared to both 2010 and 2050 baseline levels. Thus, these scenarios bring the highest co-benefits in terms of GWP and PMF reduction. Nonetheless, a shift toward renewable energies is not devoid of environmental impacts. While contributing to significantly reducing GHG emissions in terms of local air pollutant impacts and land and water use, the carbon abatement scenarios are the most impactful. As mentioned earlier, advanced CCS technologies and solar and wind power infrastructure consume additional water resources. Furthermore, bioenergy also requires large use of land for biomass farming activities, which leads to a massive increase in land use for energy purposes in these scenarios. Further, a large expansion of bioenergy may have serious implications on direct and indirect land use change and consequences on Amazon deforestation. MESSAGE- BRAZIL model excludes bioenergy expansion from direct land use change, as it defines an upper limit of expansion to guarantee that bioenergy does not increase pressure of deforestation, nor has implications on food security. Yet the impacts of indirect land use change are more complex to assess. These impacts are, however, pertinent, and should be further evaluated in future studies.

The higher diffusion of renewables also results in social benefits in rural areas, where plant facilities will be implemented. As highlighted by Simas and Pacca (2014) and Soria et al. (2015), implantation of wind power farms and concentrating solar power (CSP) units in rural areas in Brazil creates significant direct and indirect jobs, and raises the income of the local population.

\section{Final remarks}

The present study projected a series of energy-focused indicators to assess energy security and sustainability dimensions under increasingly stringent mitigation scenarios for Brazil within the 2050 timeframe. By resorting to the energy integrated model MESSAGE- BRAZIL, five scenarios were built and assessed. The interactions between the sustainability and security dimensions were complemented by an LCA analysis. This complementary approach has proven essential to further corroborate main interactions between integrated sustainability and security dimensions. Finally, the scenarios were compared in terms of their primary energy and electricity generation mix, and according to a list of eight indicators.

Overall, the results show that climate change mitigation policies can have synergies with other sustainability and security dimensions. While reducing GHG emissions, coal with CCS would increase water depletion and dependence on foreign energy resources, as the Tax scenarios showed. Carbon abatement scenarios have enabled simultaneous improvement of several indicators within and amongst different dimensions. By reducing GHG and PMF emissions while increasing diversity and decreasing foreign dependency, these scenarios have contributed simultaneously toward the sustainability and security dimensions. Notwithstanding, this convergence is not extensive to all indicators featured within the environmental dimension, namely land use and water depletion Also, reducing GHG emissions through the extensive use of biomass has impacts on the primary energy intensity of the country, given their lower conversion efficiency. 
Some limitations of the modelling approach used in this study should be mentioned. MESSAGEBRAZIL optimizes for a vector of exogenous energy service demand, which, in turn, is based on GDP assumptions. It is reasonable to expect that stringent mitigation scenarios would affect GDP growth rates and, thus, energy service demands. Also, by being an integrated energy system expansion model, the representation of operational aspects of the power system is simplified. Soft linking MESSAGE- BRAZIL to a detailed operation model might provide useful insights into the power sector. Finally, the representation of energy efficiency measures in MESSAGE- BRAZIL is limited. Therefore, mitigation options available to the model are concentrated on supply side measures, leaving important alternatives out of the analysis.

The results of this paper reflect the complexity of interactions involved in energy planning decision making, as tackling different dimensions of sustainability cannot be easily achieved within a single scenario. Therefore, increasing the portfolio of energy technology options may provide additional flexibility to cope with conflicting issues. Also, it would be worth conducting sensitivity analyses to assess key uncertainties in scenario building. It is also necessary to extend the analysis to other energy sectors to promote a better understanding of repercussions of mitigation policies in the energy security and sustainability dimensions. Finally, future work should expand the dimensions evaluated in this study by adding other EISD.

\section{Acknowledgements}

This work was funded by the Brazilian research funding agencies CNPq and CAPES, under the Science Without Borders Programme, and the Marie Curie International Research Staff Exchange Scheme Fellowship within the $7^{\text {th }}$ European Union Framework Programme, under the project NETEP- European Brazilian Network on Energy Planning (PIRSES-GA-2013-612263). We also acknowledge funding from US EPA and US AID (under Interagency Agreements DW89923040 and DW89923951US), through the LAMP, and the European Union, through the CLIMACAP project (EuropeAid/131944/C/SER/Multi).

The authors are also thankful for the anonymous reviewers' comments, which improved considerably the manuscript. 


\section{Annex}

Table A1. Cost and performance of the electricity generation technologies

\begin{tabular}{|c|c|c|c|c|c|c|c|c|c|}
\hline \multirow[b]{2}{*}{ Power plant options } & \multicolumn{2}{|c|}{$\begin{array}{l}\text { Investment } \\
\text { cost } \\
\text { (US\$/kW) }\end{array}$} & \multicolumn{2}{|c|}{$\begin{array}{c}\text { Variable } \\
\text { O\&M cost } \\
\text { (US\$/MWh) }\end{array}$} & \multicolumn{2}{|c|}{$\begin{array}{c}\text { Fixed } \\
\text { O\&M cost } \\
\text { (US\$/kW/year) }\end{array}$} & \multicolumn{2}{|c|}{$\begin{array}{c}\text { Conversion } \\
\text { efficiency }\end{array}$} & \multirow[t]{2}{*}{$\begin{array}{l}\text { Availab } \\
\text { ility }\end{array}$} \\
\hline & 2010 & 2050 & 2010 & 2050 & 2010 & 2050 & 2010 & 2050 & \\
\hline \multicolumn{10}{|l|}{ Coal ${ }^{\mathrm{a}}$} \\
\hline Domestic coal-FBC & 3,690 & 2,500 & 4.6 & 3.1 & 39 & 26 & 0.38 & 0.42 & 0.85 \\
\hline FBC with CCS & 4,190 & 3,000 & 8.1 & 6.2 & 91 & 78 & 0.22 & 0.34 & 0.85 \\
\hline Pulverized imported & & & & & & & & & \\
\hline coal -PC & 2,000 & 2,000 & 5.6 & 5.6 & 38 & 38 & 0.40 & 0.45 & 0.85 \\
\hline PC with CCS & 2,500 & 2,500 & 9.1 & 9.1 & 90 & 90 & 0.23 & 0.36 & 0.85 \\
\hline IGCC (imported coal) & 2,400 & 2,400 & 3.5 & 3.5 & 28 & 28 & 0.40 & 0.48 & 0.85 \\
\hline IGCC with CCS & 2,600 & 2,600 & 7.1 & 7.1 & 54 & 54 & 0.35 & 0.42 & 0.85 \\
\hline $\begin{array}{l}\text { Co-firing of domestic } \\
\text { coal and biomass }\end{array}$ & 3,690 & 2,500 & 4.6 & 3.1 & 39 & 26 & 0.35 & 0.40 & 0.85 \\
\hline \multicolumn{10}{|l|}{ Natural gas (NG) ${ }^{b}$} \\
\hline OCGT & 800 & 600 & 3.5 & 3.5 & 20 & 15 & 0.35 & 0.38 & 0.90 \\
\hline CCGT & 1,190 & 1,000 & 3.5 & 3.5 & 13 & 11 & 0.50 & 0.55 & 0.85 \\
\hline CCGT with CCS & 3,090 & 3,090 & 3.5 & 3.5 & 23 & 23 & 0.43 & 0.43 & 0.85 \\
\hline Flexible CCGT & 1,300 & 1,300 & 3.5 & 3.5 & 13 & 13 & 0.55 & 0.58 & 0.85 \\
\hline \multicolumn{10}{|l|}{ Hydroelectric ${ }^{c}$} \\
\hline \multicolumn{10}{|l|}{ Small hydroelectric } \\
\hline$(<30 \mathrm{MW})$ & 2,936 & 2,936 & - & - & 65 & 65 & - & - & $*$ \\
\hline $\begin{array}{l}\text { Medium hydroelectric } \\
(>30 \mathrm{MW}:<300 \mathrm{MW})\end{array}$ & 2,513 & 2,513 & _- & - & 58 & 58 & - & - & * \\
\hline Large hydroelectric & & & & & & & & & \\
\hline$(>300 \mathrm{MW})$ & 2,091 & 2,091 & - & - & 52 & 52 & - & - & $*$ \\
\hline Nucleard & 4,000 & 4,000 & 0.8 & 0.8 & 136 & 136 & & & \\
\hline \multicolumn{10}{|l|}{ Biomasse } \\
\hline $\begin{array}{lr}\text { Bagasse } & \text { with } \\
\text { backpressure } & \text { turbines }\end{array}$ & & & & & & & & & \\
\hline (22 bar) & 800 & 800 & 5.6 & 5.6 & - & - & 0.25 & 0.25 & 0.90 \\
\hline Bagasse with CEST - & & & & & & & & & \\
\hline existing & 959 & 959 & 4.8 & 4.8 & - & - & 0.25 & 0.25 & 0.90 \\
\hline Bagasse with CEST - & & & & & & & & & \\
\hline new & 2,712 & 2,392 & 4.6 & 4.6 & - & - & 0.30 & 0.30 & 0.90 \\
\hline Bagasse with BIG/GT & 1,009 & 1,009 & 4.8 & 4.8 & - & - & 0.40 & 0.40 & 0.80 \\
\hline Biomass -steam turbine & 3,600 & 2,500 & 6.3 & 6.3 & 50 & 50 & 0.28 & 0.28 & 0.60 \\
\hline Municipal solid waste & 7,050 & 6,210 & - & - & 211 & 186 & 0.28 & 0.28 & 0.74 \\
\hline \multicolumn{10}{|l|}{ Oil $^{f}$} \\
\hline Diesel & 1,000 & 1,000 & 14.3 & 14.3 & - & - & 0.35 & 0.35 & 0.35 \\
\hline Fuel oil & 1,070 & 1,070 & 14.3 & 14.3 & - & - & 0.30 & 0.33 & 0.55 \\
\hline \multicolumn{10}{|l|}{ Non-conventional RE } \\
\hline Solar PV-USg & 4,300 & 1,300 & - & - & 51 & 15 & - & - & 0.17 \\
\hline Solar PV-DGg & 5,300 & 2,000 & - & - & 22 & 8 & - & - & 0.17 \\
\hline Wind onshore ${ }^{f}$ & 1,810 & 1,547 & - & - & 42 & 36 & - & - & 0.35 \\
\hline Wind offshore ${ }^{f}$ & 5,000 & 3,000 & - & - & 60 & 36 & - & - & 0.40 \\
\hline Wave $^{f}$ & 6,000 & 4,500 & - & - & 20 & 20 & - & - & 0.15 \\
\hline Solar CSP-4hTESh & 5,208 & 3,315 & - & - & 85 & 54 & - & - & 0.32 \\
\hline Solar CSP-8hTESh & 6,312 & 3,912 & - & - & 103 & 64 & - & - & 0.37 \\
\hline Solar CSP-12hTESh & 7,254 & 4,422 & - & - & 118 & 72 & - & - & 0.42 \\
\hline Solar CSP-BIO' & 5,856 & 3,641 & 5.0 & 5.0 & 65 & 65 & 0.57 & 0.57 & 0.51 \\
\hline
\end{tabular}

Notes: * Availability of hydro power plants is presented in Table A2. Variable O\&M cost does not include fuel cost. PC: pulverized coal. FBC: fluidized-bed coal. IGCC: integrated gasification combined cycle. CCS: carbon capture and storage. OCGT: open cycle gas turbines. CCGT: combined cycle gas turbines. BIG/GT: biomass integrated gasification/gas turbines. CEST: condensing-extraction steam turbine. n.a.: not applicable. RE: renewable energy. US: utility scale. DG: distributed generation. CSP: concentrated solar power. TES: thermal energy storage. CSP-BIO: CSP power plant hybridized with biomass, without TES.

Sources:

a Hoffmann et al. (2012); Rochedo and Szklo (2013) and Borba et al. (2012)

b Black \& Veatch (2012), Deutch et al. (2009), EIA (2013, 2014), IEA (2014b), UNFCCC.Secretariat (2014). 
cLucena et al. (2010)

d Cabrera-Palmer and Rothwell (2008); Deutch et al. (2009) and NEA/IEA (2010)

e EIA (2014), IRENA (2012) and Borba et al. (2012)

${ }^{f}$ Borba et al. (2012)

g IEA (2014a)

h Fichter et al. (2014); IEA (2014d); Trieb et al. (2014).

i Soria et al. (2015)

Table A2. Availability factor of hydropower plants in Brazil

\begin{tabular}{ccc}
\hline & \multicolumn{2}{c}{ Regions } \\
Hydropower plant & South, Southeast, Midwest & North, Northeast \\
\hline Small/Medium & 0.57 & 0.60 \\
Large & 0.52 & 0.54 \\
\hline
\end{tabular}

Source: Lucena et al. (2010)

\section{References}

Black \& Veatch, 2012. Cost and Performance Data for Power Generation Technologies. Prepared for NREL, Black \& Veatch.

Blum, H. \& Legey, L.F.L., 2012. The challenging economics of energy security: Ensuring energy benefits in support to sustainable development. Energy Economics, 34(6), pp.1982-1989. Available at: http://linkinghub.elsevier.com/retrieve/pii/S0140988312001831 [Accessed November 27, 2013].

Borba, B., Szklo, A. \& Schaeffer, R., 2012. Plug-in hybrid electric vehicles as a way to maximize the integration of variable renewable energy in power systems: The case of wind generation in northeastern Brazil. Energy, 37(1), pp.469-481. Available at: http://linkinghub.elsevier.com/retrieve/pii/S0360544211007262 [Accessed June 5, 2014].

Cubasch, U. et al., 2013. Introduction. In: Climate Change 2013: The Physical Science Basis. Contribution of Working Group I to the Fifth Assessment Report of the Intergovernmental Panel on Climate Change,

Empresa de Pesquisa Energética (EPE/MME), 2014. Balanço Energético Nacional 2014: ano base 2013,

Goedkoop, M. et al., 2014. SimaPro Tutorial,

Goldemberg, J. et al., 2014. Oil and natural gas prospects in South America: Can the petroleum industry pave the way for renewables in Brazil? Energy Policy, 64, pp.58-70. Available at: http://dx.doi.org/10.1016/j.enpol.2013.05.064.

Greene, D.L., 2010. Measuring energy security: Can the United States achieve oil independence? Energy Policy, 38(4), pp.1614-1621.

Hedenus, F., Azar, C. \& Johansson, D.J. a, 2010. Energy security policies in EU-25-The expected cost of oil supply disruptions. Energy Policy, 38(3), pp.1241-1250. 
Herreras Martínez, S. et al., 2015. Possible energy futures for Brazil and Latin America in conservative and stringent mitigation pathways up to 2050. Technological Forecasting and Social Change. Available at: http://linkinghub.elsevier.com/retrieve/pii/S0040162515001225.

IAEA and UNDESA, 2007. Energy Indicators for Sustainable Development: Country Studies on Brazil, Cuba, Lithuania, Mexico, Russian Federation, Slovakia and Thailand,

Intergovernmental, C. of W.G.I. to the F.A.R. of the \& Panel on Climate Change [Stocker, T.F., D. Qin, G.-K. Plattner, M. Tignor, S.K. Allen, J. Boschung, A. Nauels, Y. Xia, V.B. and P.M.M., 2013. Climate Change 2013, Cambridge, United Kingdom and New York, NY, USA.

Johansson, B., 2013. Security aspects of future renewable energy systems-A short overview. Energy, 61, pp.598-605.

Knox-Hayes, J. et al., 2013. Understanding attitudes toward energy security: Results of a crossnational survey. Global Environmental Change, 23(3), pp.609-622.

Löschel, A., Moslener, U. \& Rübbelke, D.T.G., 2010. Indicators of energy security in industrialised countries. Energy Policy, 38(4), pp.1665-1671.

Lucena, A.F., Schaeffer, R. \& Szklo, A.S., 2010. Least-cost adaptation options for global climate change impacts on the Brazilian electric power system. Global Environmental Change, 20(2), pp.342-350. Available at: http://dx.doi.org/10.1016/j.gloenvcha.2010.01.004.

Lucena, A.F.P. et al., 2015. Climate Policy Scenarios in Brazil: A Multi-Model Comparison for Energy. Energy Economics.

Lucena, A.F.P. et al., 2009. The vulnerability of renewable energy to climate change in Brazil. Energy Policy, 37(3), pp.879-889.

Malagueta, D. et al., 2014. Potential and impacts of Concentrated Solar Power (CSP) integration in the Brazilian electric power system. Renewable Energy, 68(August 2014), pp.223-235.

Martchamadol, J. \& Kumar, S., 2014. The Aggregated Energy Security Performance Indicator (AESPI) at national and provincial level. Applied Energy, 127, pp.219-238.

Merschmann, P.R.D.C. et al., 2013. International Journal of Greenhouse Gas Control Modeling water use demands for thermoelectric power plants with CCS in selected Brazilian water basins. International Journal of Greenhouse Gas Control, 13, pp.87-101. Available at: http://dx.doi.org/10.1016/j.ijggc.2012.12.019.

Moreira, J.R., Pacca, S. a. \& Parente, V., 2014. The future of oil and bioethanol in Brazil. Energy Policy, 65, pp.7-15.

Narula, K. \& Reddy, B.S., 2015. Three blind men and an elephant: The case of energy indices to measure energy security and energy sustainability. Energy, 80, pp.148-158. Available at: http://linkinghub.elsevier.com/retrieve/pii/S0360544214013103. 
Nogueira, L.P.P., Frossard Pereira de Lucena, A., Rathmann, R., Rochedo, P., et al., 2014. Will thermal power plants with CCS play a role in Brazil's future electric power generation? International Journal of Greenhouse Gas Control, 24, pp.115-123.

Nuttall, W.J. \& Manz, D.L., 2008. A new energy security paradigm for the twenty-first century. Technological Forecasting and Social Change, 75(8), pp.1247-1259.

Percebois, J., 2007. Energy vulnerability and its management. International Journal of Energy Sector Management, 1(1), pp.51-62.

Portugal-pereira, J. \& Esteban, M., 2014. Implications of paradigm shift in Japan 's electricity security of supply: A multi-dimensional indicator assessment. Applied Energy, 123, pp.424-434. Available at: http://dx.doi.org/10.1016/j.apenergy.2014.01.024.

Ren, J. \& Sovacool, B.K., 2014. Enhancing China's energy security: Determining influential factors and effective strategic measures. Energy Conversion and Management, 88, pp.589-597. Available at: http://linkinghub.elsevier.com/retrieve/pii/S0196890414007894.

Ren, J. \& Sovacool, B.K., 2015. Prioritizing low-carbon energy sources to enhance China' s energy security. Energy Conversion and Management, 92, pp.129-136. Available at: http://dx.doi.org/10.1016/j.enconman.2014.12.044.

Santos, M. et al., Scenarios for the future Brazilian power system based on a multi-criteria assessment. J.Cleaner Production (submitted).

Saraiva, T.A. et al., 2014. Forecasting Brazil's crude oil production using a multi-Hubbert model variant. Fuel, 115(2014), pp.24-31.

Schaeffer, R. et al., 2012. Energy sector vulnerability to climate change: A review. Energy, 38(1), pp.1-12. Available at: http://dx.doi.org/10.1016/j.energy.2011.11.056.

Schaeffer, R. et al., 2005. Indicators for sustainable energy development: Brazil's case study. Natural Resources Forum, UN, 29(4), pp.284-297.

Simas, M. \& Pacca, S., 2014. Assessing employment in renewable energy technologies: A case study for wind power in Brazil. Renewable and Sustainable Energy Reviews, 31, pp.83-90. Available at: http://dx.doi.org/10.1016/j.rser.2013.11.046.

Soito, J.L.D.S. \& Freitas, M. a V, 2011. Amazon and the expansion of hydropower in Brazil: Vulnerability, impacts and possibilities for adaptation to global climate change. Renewable and Sustainable Energy Reviews, 15(6), pp.3165-3177.

Solomon, S., D. Qin, M. Manning, Z. Chen, M. Marquis, K.B.A. \& Miller, M.T. and H.L., 2007. Climate change 2007, United Kingdom and New York, NY, USA.

Soria, R. et al., 2015. Hybrid concentrated solar power (CSP)-biomass plants in a semiarid region: A strategy for CSP deployment in Brazil. Energy Policy, 86(March 2014), pp.57-72. Available at: http://linkinghub.elsevier.com/retrieve/pii/S0301421515002463.

Sovacool, B.K. \& Mukherjee, I., 2011. Conceptualizing and measuring energy security: A synthesized approach. Energy, 36(8), pp.5343-5355. Available at: 
http://linkinghub.elsevier.com/retrieve/pii/S0360544211004294 [Accessed November 15, 2013].

Von Sperling, E., 2012. Hydropower in Brazil: Overview of positive and negative environmental aspects. Energy Procedia, 18, pp.110-118. Available at: http://dx.doi.org/10.1016/j.egypro.2012.05.023.

Vivoda, V., 2010. Evaluating energy security in the Asia-Pacific region: A novel methodological approach. Energy Policy, 38(9), pp.5258-5263. Available at: http://linkinghub.elsevier.com/retrieve/pii/S030142151000399X [Accessed November 27, 2013].

World Nuclear Association, 2013. Cooling power plants, London. UK. Available at: http://www.world-nuclear.org/info/Current-and-Future-Generation/Cooling-PowerPlants/\#.Udx22awzZqM (July 2015) 